\title{
Performance and microbial community composition dynamics of aerobic granular sludge from sequencing batch bubble column reactors operated at $20{ }^{\circ} \mathrm{C}, 30^{\circ} \mathrm{C}$, and $35^{\circ} \mathrm{C}$
}

\author{
Sirous Ebrahimi • Sébastien Gabus • \\ Emmanuelle Rohrbach-Brandt • Maryam Hosseini • \\ Pierre Rossi • Julien Maillard • Christof Holliger
}

Received: 4 March 2010/Revised: 12 April 2010 /Accepted: 13 April 2010 /Published online: 12 May 2010

(C) Springer-Verlag 2010

\begin{abstract}
Two bubble column sequencing batch reactors fed with an artificial wastewater were operated at $20{ }^{\circ} \mathrm{C}, 30{ }^{\circ} \mathrm{C}$, and $35^{\circ} \mathrm{C}$. In a first stage, stable granules were obtained at $20{ }^{\circ} \mathrm{C}$, whereas fluffy structures were observed at $30{ }^{\circ} \mathrm{C}$. Molecular analysis revealed high abundance of the operational taxonomic unit 208 (OTU 208) affiliating with filamentous bacteria Leptothrix spp. at $30{ }^{\circ} \mathrm{C}$, an OTU much less abundant at $20{ }^{\circ} \mathrm{C}$. The granular sludge obtained at $20{ }^{\circ} \mathrm{C}$ was used for the second stage during which one reactor was maintained at $20^{\circ} \mathrm{C}$ and the second operated at $30^{\circ} \mathrm{C}$ and
\end{abstract}

Electronic supplementary material The online version of this article (doi:10.1007/s00253-010-2621-4) contains supplementary material, which is available to authorized users.

S. Ebrahimi - S. Gabus $\cdot$ E. Rohrbach-Brandt $\cdot$ M. Hosseini $\cdot$

P. Rossi $\cdot$ J. Maillard $\cdot$ C. Holliger

Ecole Polytechnique Fédérale de Lausanne (EPFL),

Laboratory for Environmental Biotechnology,

Lausanne, Switzerland

C. Holliger $(\square)$

EPFL ENAC IIE LBE,

Station 6 ,

1015 Lausanne, Switzerland

e-mail: christof.holliger@epfl.ch

Present Address:

S. Ebrahimi $\cdot$ M. Hosseini

Department of Chemical Engineering,

Sahand University of Technology,

Tabriz, Iran

Present Address:

P. Rossi

EPFL ENAC IIE CEL,

Station 2,

1015 Lausanne, Switzerland
$35{ }^{\circ} \mathrm{C}$ after prior gradual increase of temperature. Aerobic granular sludge with similar physical properties developed in both reactors but it had different nutrient elimination performances and microbial communities. At $20^{\circ} \mathrm{C}$, acetate was consumed during anaerobic feeding, and biological phosphorous removal was observed when Rhodocyclaceaeaffiliating OTU 214 was present. At $30^{\circ} \mathrm{C}$ and $35^{\circ} \mathrm{C}$, acetate was mainly consumed during aeration and phosphorous removal was insignificant. OTU 214 was almost absent but the Gammaproteobacteria-affiliating OTU 239 was more abundant than at $20{ }^{\circ} \mathrm{C}$. Aerobic granular sludge at all temperatures contained abundantly the OTUs 224 and 289 affiliating with Sphingomonadaceae indicating that this bacterial family played an important role in maintaining stable granular structures.

Keywords Wastewater treatment - Nutrient removal . Biological dephosphatation - Aerobic granular sludge

\section{Introduction}

Aerobic granular sludge-based reactors represent an attractive alternative to conventional activated sludge systems due to their small footprint and low excess sludge production (de Bruin et al. 2004). The sludge developed in such systems has high biomass concentration, good settling properties, high chemical oxygen demand (COD) removal efficiency, and high phosphorus removal capacity (de Kreuk et al. 2005a). In addition, and depending on bulk oxygen concentration and granule size, simultaneous nitrification-denitrification can occur in granules (Beun et al. 2001; Mosquera-Corral et al. 2005). Aerobic granular sludge has mainly been developed in sequencing batch 
reactor (SBR) systems, some using airlift or bubble column reactors. Several laboratory scale studies have been carried out to identify the most important factors influencing both the aerobic granular sludge formation and the catalyzed conversion processes. The state of the art of this novel aerobic wastewater treatment technology has been presented in different recent reviews (Liu and Tay 2004; de Kreuk et al. 2007).

The presence of slow-growing microorganisms such as polyphosphate and glycogen accumulating organisms (PAO and GAO, respectively) is apparently a key factor in order to get dense and stable aerobic granules (de Kreuk and van Loosdrecht 2004). These organisms have been selected in an aerobic granular sludge SBR by application of a feast/ famine regime. Characterization of these aerobic granules using fluorescence in situ hybridization techniques has shown the presence of PAO and nitrifiers which was in agreement with the microbial processes occurring in the reactors (de Kreuk et al. 2005a; Wilen et al. 2008). One study on granules of a reactor treating a wastewater containing tert-butyl alcohol showed a stable microbial community composition during a period of 4 weeks and showed the presence of mainly Proteobacteria (Tay et al. 2005). The characterization of the microbial community of highly filamentous granules using DGGE showed that the biomass was dominated by filamentous bacteria, Zoogloea ramigera, and fungi (Williams and Reyes 2006).

In traditional enhanced biological phosphorus removal (EBPR) systems, numerous studies have been carried out to investigate the microbial communities of the activated sludge. Polyphosphate accumulating Rhodocyclus-affiliated bacteria that belong to Betaproteobacteria have been identified as major population responsible for biological phosphorous removal (Hesselmann et al. 1999; Crocetti et al. 2000). In the EBPR process, PAO can be outcompeted by GAO leading to deterioration of the performance of the system (Filipe et al. 2001; Saunders et al. 2003). Members of the GAO guild identified in activated sludge belong to Alpha- as well as Gammaproteobacteria (Crocetti et al. 2002; Meyer et al. 2006). Temperature has been shown to be a key factor influencing PAO-GAO competition (Whang and Park 2002; Panswad et al. 2003; Oehmen et al. 2004; Whang and Park 2006; Lopez-Vazquez et al. 2007). In general, it can be concluded from these studies that activities of the biological phosphorus removal process deteriorates at temperatures higher than $20{ }^{\circ} \mathrm{C}$ and GAO become the dominant microorganisms. As temperature increases to $35{ }^{\circ} \mathrm{C}$, both $\mathrm{PAO}$ and $\mathrm{GAO}$ disappear and ordinary heterotrophic organisms become predominant (Panswad et al. 2003).

In most studies on aerobic granular sludge, SBRs (GS-SBR) have been operated at ambient temperature, e.g., $20-25{ }^{\circ} \mathrm{C}$ (Morgenroth et al. 1997; de Kreuk and van Loosdrecht 2004;
Whang and Park 2006) or lower (de Kreuk et al. 2005b). Thermophilic granular sludge has also been produced at temperatures as high as $55{ }^{\circ} \mathrm{C}$ (Zitomer et al. 2007). Regarding the proposed importance of both PAO and GAO in the formation, stability, and density of aerobic granules, investigation of the temperature effect (from $20^{\circ} \mathrm{C}$ to $35^{\circ} \mathrm{C}$ ) was the main purpose of the present study. The performance and stability of the granular sludge obtained at different temperatures was investigated and compared with the structure and composition of the microbial communities present in the different granules.

\section{Materials and methods}

\section{Reactor setup and operation}

The reactor setup and operation was very similar to the one used by de Kreuk and van Loosdrecht (2004). Two doublewalled bubble column sequencing batch reactors (BC-SBR) with an internal diameter of $6.15 \mathrm{~cm}$ were used (working volume $2.6 \mathrm{~L}$ ). The two BC-SBRs were inoculated with $300 \mathrm{~mL}$ of activated sludge from the Thunersee wastewater treatment plant (Thun, Switzerland), a plant that removes N and $\mathrm{P}$ biologically. Air was introduced via a fine bubble aerator at the bottom of the reactor at a rate of $4 \mathrm{~L} \mathrm{~min}^{-1}$ and there was no oxygen control. During the first-stage experiment, temperature was controlled at $30{ }^{\circ} \mathrm{C}$ in reactor $\mathrm{A}$ and at $20{ }^{\circ} \mathrm{C}$ in reactor $\mathrm{B}$. In the second-stage experiment, temperature of reactor $\mathrm{B}$ was maintained at $20{ }^{\circ} \mathrm{C}$. Reactor A was operated first at $25{ }^{\circ} \mathrm{C}$ during 12 days, then for 9 days at $28{ }^{\circ} \mathrm{C}$, for 48 days at $30^{\circ} \mathrm{C}$, and finally for 34 days at $35^{\circ} \mathrm{C}$. The $\mathrm{pH}$ was measured online and maintained at $7.0 \pm 0.2$ by dosing $1 \mathrm{M} \mathrm{NaOH}$ or $1 \mathrm{M}$ $\mathrm{HCl}$. Hydraulic retention time and substrate load were $6 \mathrm{~h}$

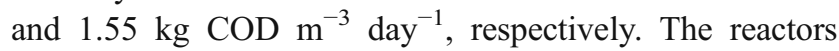
were operated in successive cycles of $3 \mathrm{~h}$ divided in $60 \mathrm{~min}$ slow feeding from the bottom of the reactor under anaerobic conditions, $110 \mathrm{~min}$ aeration, $5 \mathrm{~min}$ settling (to keep only particles settling faster than $6 \mathrm{~m} \mathrm{~h}^{-1}$ in the reactor), and $5 \mathrm{~min}$ effluent discharge. The reactors were fed with the same medium as the one used by de Kreuk et al. (2005a). It was prepared as two stock solutions that were mixed with tap water prior to feeding. Solution A contained sodium acetate $(63 \mathrm{mM}), \mathrm{MgSO}_{4} \cdot 7 \mathrm{H}_{2} \mathrm{O}(3.6 \mathrm{mM})$ and $\mathrm{KCl}(4.8 \mathrm{mM})$. Solution B contained $\mathrm{NH}_{4} \mathrm{Cl}(35.4 \mathrm{mM}), \mathrm{K}_{2} \mathrm{HPO}_{4}(4.2 \mathrm{mM})$, $\mathrm{KH}_{2} \mathrm{PO}_{4}(2.1 \mathrm{mM})$, and $10 \mathrm{~mL} \mathrm{~L}^{-1}$ trace element solution. The trace element stock solution contained: EDTA $342.2 \mathrm{mmol} \mathrm{L}^{-1}, \mathrm{ZnSO}_{4} \cdot 7 \mathrm{H}_{2} \mathrm{O} 15.3 \mathrm{mmol} \mathrm{L}-1, \mathrm{CaCl}_{2} \cdot 2 \mathrm{H}_{2} \mathrm{O}$ $111.3 \mathrm{mmol} \mathrm{L}^{-1}, \mathrm{MnCl}_{2} \cdot 4 \mathrm{H}_{2} \mathrm{O} 51.1 \mathrm{mmol} \mathrm{L}^{-1}, \mathrm{FeSO}_{4} \cdot 7 \mathrm{H}_{2} \mathrm{O}$ $35.9 \mathrm{mmol} \mathrm{L}^{-1}, \mathrm{Na}_{2} \mathrm{Mo}_{7} \mathrm{O}_{24} \cdot 2 \mathrm{H}_{2} \mathrm{O} 2.7 \mathrm{mmol} \mathrm{L} \mathrm{L}^{-1}$, $\mathrm{CuSO}_{4} \cdot 5 \mathrm{H}_{2} \mathrm{O} 12.6 \mathrm{mmol} \mathrm{L}{ }^{-1}$, and $\mathrm{CoCl}_{2} \cdot 6 \mathrm{H}_{2} \mathrm{O} 13.5 \mathrm{mmol}$ $\mathrm{L}^{-1}$. Per cycle, $125 \mathrm{~mL}$ of both solutions were added to the 
reactor by peristaltic pumps together with $1,050 \mathrm{~mL}$ of tap water.

Granules characterization and chemical analysis

Morphology of the granules, dry weight and ash content of the granules, total organic carbon, COD, acetate, and biomass concentration in the bulk liquid were measured as described by Beun et al. (2002). Characterization of the morphology of the granules (particle diameter, aspect ratio, and shape factor) was restricted to particles with a surface $>0.05 \mathrm{~mm}^{2}$. Density of the biomass was determined as described by Beun et al. (2002). $\mathrm{NH}_{4}{ }^{+}, \mathrm{NO}_{2}{ }^{-}$and $\mathrm{NO}_{3}{ }^{-}$, and $\mathrm{PO}_{3}{ }^{4-}$ concentrations in the bulk liquid were determined spectrophotometrically with standard test kits (MERCK, Ammonium test 14752, Nitrate test 09713, Nitrite test 14776, Phosphate test 14848). The sludge volume index $\left(\mathrm{SVI}_{8}\right)$ was determined by reading the height of the settled bed in the reactor after 8 min settling and calculated from the settled bed volume and the dry weight in the reactor. Conversion rates and removal efficiencies were calculated as described by Mosquera-Corral et al. (2005). Conversion rates were averaged from at least two cycle measurements, and removal efficiencies were determined as an average from a stable period of at least 3 weeks in each experimental stage. The stage during which both nutrient consumption and sludge bed height were stable was considered as steady state. To determine P content of granules, sludge sample were digested with a standard kit using potassium persulfate (MERCK, crack test 1.14687), and $\mathrm{PO}_{3}{ }^{4-}$ concentration of the supernatant recovered by high speed centrifugation was determined. Dry weight concentration in the effluent was measured after centrifugation of the entire effluent of the reactor and drying the pellet at $105{ }^{\circ} \mathrm{C}$ for $24 \mathrm{~h}$.

Sludge sample collection

Bulk solution reactor samples of a volume of $15 \mathrm{~mL}$ were collected at least once a week by a $50-\mathrm{mL}$ syringe at two different heights of the bubble column. Granules were then disaggregated using a pestle and mortar. The samples were then centrifuged for $20 \mathrm{~min}$ at $3,500 \times \mathrm{g}$. Supernatant was removed and pellet stored at minus $20{ }^{\circ} \mathrm{C}$.

DNA extraction and PCR amplification

Total community DNA was extracted from about $500 \mu \mathrm{L}$ of pellet material using the MoBio Power soil extraction kit (MoBio, Solana beach, CA, USA). Amplification of the 16S rRNA genes was performed with universal primers for the domain bacteria: 8-F (5'-GAGTTTGATCMTGGCT CAG-3') and 518R (5'-ATTACCGCGGCTGCTGG-3') for both T-RFLP and clone library. PCR was carried out using $5 \mathrm{ng}$ of DNA in a final volume of $50 \mu \mathrm{l}$. The cycle profiles used were initial denaturation for $4 \mathrm{~min}$ and $30 \mathrm{~s}$ at $95^{\circ} \mathrm{C}$, denaturation for $30 \mathrm{~s}$ at $95{ }^{\circ} \mathrm{C}$, primer annealing at $56{ }^{\circ} \mathrm{C}$ for $45 \mathrm{~s}$, and elongation for $1 \mathrm{~min}$ at $72{ }^{\circ} \mathrm{C}$; the number of cycles was 25 . Triplicate reactions were pooled and DNA concentrated and cleaned using a Microcon-PCR purification kit (Millipore, Billerica, MA, USA). For each sample, DNA concentration was adjusted to $100 \mathrm{ng}$ final concentration prior to further use.

\section{Cloning of 16S rRNA genes}

Clone libraries of 16S rRNA gene pools were obtained by cloning purified PCR products into the pGEM-T Easy vector system (Promega). Transformants were selected with standard blue-white screening on LB plates according to the manufacturer's instructions. Plasmid DNA was extracted and purified with the E.Z.N.A. Plasmid Miniprep Kit I (PeqLab). The purified plasmids were sequenced using primer $\mathrm{T} 7$ and the ABI V3.1 BigDye terminator cycle sequencing ready reaction kit (Applied Biosystems) on an ABI3100 automated capillary DNA sequencer. Sequence analysis was performed with the DNAStar package and compared to the GenBank database using BLAST (Maidak et al. 1996; Altschul et al. 1997). Potential chimeric sequences as detected by the RDP Chimera Check program were discarded and sequences were classified using other tools available on the RDP web site (http://rdp.cme.msu.edu/index.jsp).

\section{T-RFLP analysis}

PCR products were generated with a combination of HEXlabeled $8 \mathrm{~F}$ and unlabelled $518 \mathrm{R}$ primers according to the above mentioned conditions. Purified PCR products from each DNA sample were quantified (NanoDrop, ND-1000 Spectrophotometer) and aliquots of $50 \mathrm{ng}$ were digested with 1 unit of the restriction enzyme HaeIII (Promega) at $37{ }^{\circ} \mathrm{C}$ for $4 \mathrm{~h}$. Digested samples $(1 \mu \mathrm{L})$ was mixed with $8.5 \mu \mathrm{L}$ of HiDi formamid (ABI) and $0.5 \mu \mathrm{L}$ of GS500ROX standard (ABI). Samples were denatured by heating to $95{ }^{\circ} \mathrm{C}$ for $2 \mathrm{~min}$ followed by cooling on ice for $5 \mathrm{~min}$. The denatured samples were loaded onto an ABI3100 capillary DNA sequencer equipped with $50 \mathrm{~cm}$ long capillaries and POP 6 electrophoresis matrix according to the manufacturer's instructions. The resulting datasets were analyzed with Genescan (ABI). Each digested sample was run in triplicate, and the resulting composite profiles (percentage of contribution of all peak areas) were aligned semi-manually using Treeflap (http://www.sci.monash.edu. $\mathrm{au} / \mathrm{wsc} / \mathrm{staff} / \mathrm{walsh} /$ treeflap.xls). Terminal restriction fragments (T-RFs) among replicates that differed by less than $0.5 \mathrm{bp}$ were considered identical and assigned to the 
averaged size. A baseline was set to nine times the background noise (ten relative fluorescent units in peak height), and all T-RFs below this limit were discarded. Likewise, all T-RFs showing a relative contribution (in terms of peak area) smaller than $0.3 \%$ (relative to the whole profile) were discarded. Numerical treatment and analysis of the data were carried out with R (http://www.r-project.org/index.html) and the Vegan library. The Ruzicka dissimilarity is defined on the basis of the Jaccard similarity (Legendre and Legendre 1998), which does not consider the double absence of a band as a resemblance between two profiles. Ranging from 0 (identical profiles) to 1 (very different profiles with no band in common), it takes into account the relative intensity of all T-RFs within the whole fingerprinting patterns. All clone sequences shown herein have been deposited in the GenBank database under accession numbers GU727739 to GU727811.

\section{Results}

In this study, the effect of temperature on granule formation, nutrient removal performances, and microbial community composition was studied in two stages. The first stage was stopped after 67 days of reactor operation due to the low quality of the aerobic granular sludge obtained at $30{ }^{\circ} \mathrm{C}$. The second stage was started with the granular sludge from the first stage BC-SBR operated at $20{ }^{\circ} \mathrm{C}$. Higher mesophilic temperatures were reached by a stepwise increase of temperature giving the microbial community of the $20{ }^{\circ} \mathrm{C}$-sludge time to adapt to higher temperatures. In the following, the granular sludge properties, the nutrient removal performances, and the microbial community structures are described for the two stages and the different operation temperatures.

\section{Granular sludge properties}

\section{First-stage experiment}

Two BC-SBRs were started under identical operation conditions except temperature, one was operated at $30{ }^{\circ} \mathrm{C}$ (reactor A), the other at $20^{\circ} \mathrm{C}$ (reactor B). The settling time was fixed at $15 \mathrm{~min}$ for the first 2 days allowing particles with a settling velocity $>2 \mathrm{~m} \mathrm{~h}^{-1}$ to be retained in the reactor. It was reduced to $10 \mathrm{~min}$ for days $3-5$, to $7 \mathrm{~min}$ for days $6-7$, to $5 \mathrm{~min}$ for days $8-13$, and finally to $3 \mathrm{~min}$ from day 14 onward. The settling time was again increased to 5 min from day 38 onward due to too large loss of biomass through the effluent.

First granules were observed already after a few days of operation and 3 weeks after start-up of reactor $\mathrm{B}$, an important amount of granules could be observed. Biomass was a mixture of smooth and fluffy granules. On day 36 , dry weight in the reactor already reached $3 g_{\mathrm{VSS}} \mathrm{L}^{-1}$ and fluffy particles totally disappeared. After 64 days of operation, dry weight in the reactor was $4 \mathrm{~g}_{\mathrm{VSS}} \mathrm{L}^{-1}$ and a $\mathrm{SVI}_{8}$ of $85 \mathrm{~mL} \mathrm{~g}_{\mathrm{TSS}}{ }^{-1}$ was measured. The density of the granules was about $47 \mathrm{~g}_{\mathrm{vss}}$ $\mathrm{L}_{\text {biomass }}{ }^{-1}$. The average diameter of the granules was $1.3 \mathrm{~mm}$, and the color was slightly orange.

One week after start-up of Reactor A, a mixture of smooth and fluffy granules was also observed. The fluffy granules led to partial washout of the biomass, and the reactor had to be cleaned regularly to avoid excessive bacterial wall growth. Fluffy granules progressively disappeared from the system and the biomass was composed of a mixture of smooth granules and irregular floccular structures. The color of the granules was white. From day 8 to day 43 , the dry weight increased slowly from 0.2 to $0.75 \mathrm{~g}_{\mathrm{VSS}} \mathrm{L}^{-1}$ but decreased again to reach $0.42 \mathrm{~g}_{\mathrm{VSS}} \mathrm{L}^{-1}$ on day 64. In the same time period from days 43 to 64 , the $\mathrm{SVI}_{8}$ decreased from 365 to $153 \mathrm{~mL} \mathrm{~g}_{\mathrm{TSS}}{ }^{-1}$, the density of the granules increased from 13.2 to $42.6 \mathrm{~g}_{\mathrm{VSS}} \mathrm{L}_{\text {biomass }}{ }^{-1}$, and the solid retention time increased from 2.5 to 5 days. Despite the improved sludge properties and the observation of a complete acetate removal, the amount of biomass present in the reactor was dramatically low. Therefore, the operation of both reactors was stopped on day 67 .

\section{Second-stage experiment}

The second-stage experiment was performed using the granules developed in reactor $\mathrm{B}$ operated at $20^{\circ} \mathrm{C}$. The sludge bed was divided in two and used as seed for the start-up of the second stage. Reactor $\mathrm{B}$ was again operated at $20^{\circ} \mathrm{C}$ whereas reactor A was set at $25^{\circ} \mathrm{C}$ as initial temperature. After 12 days of operation, the temperature was increased to $28{ }^{\circ} \mathrm{C}$ for 9 days, to $30^{\circ} \mathrm{C}$ for 48 days, and finally, to $35^{\circ} \mathrm{C}$ for 34 days.

After 40 days of operation at $20{ }^{\circ} \mathrm{C}$ in reactor $\mathrm{B}$, the granular sludge bed reached a steady state volume of $0.87 \mathrm{~L}$, and the sludge had a $\mathrm{SVI}_{8}$ of about $38 \mathrm{~mL} \mathrm{~g}_{\mathrm{TSS}}{ }^{-1}$ and a density of $75 \mathrm{~g}_{\mathrm{VSS}} \mathrm{L}_{\text {biomass }}{ }^{-1}$ (Fig. 1). In reactor A with stepwise increase of temperature, steady state was reached in about the same time period of 40 days. The $\mathrm{SVI}_{8}$ of $27 \mathrm{~mL} \mathrm{~g}_{\mathrm{TSS}}{ }^{-1}$ at $30^{\circ} \mathrm{C}$ was significantly lower than the one observed at $20{ }^{\circ} \mathrm{C}$ but increased again at $35{ }^{\circ} \mathrm{C}$ to $35 \mathrm{~mL} \mathrm{~g}_{\mathrm{TSS}}{ }^{-1}$. The granular sludge bed was much smaller at higher temperatures with a volume $0.35 \mathrm{~L}$. However, the density of the granules was higher at $30^{\circ} \mathrm{C}$ and $35^{\circ} \mathrm{C}$ than at $20{ }^{\circ} \mathrm{C}\left(120 \mathrm{~g}_{\text {VSS }} \mathrm{L}_{\text {biomass }}{ }^{-1}\right.$ and $108 \mathrm{~g}_{\text {VSS }} \mathrm{L}_{\text {biomass }}{ }^{-1}$, respectively). Suspended solid concentration at $30{ }^{\circ} \mathrm{C}$ was about half of the value observed at $20{ }^{\circ} \mathrm{C}$ (4.8 versus $8.6 \mathrm{~g}_{\mathrm{TSS}} \mathrm{L}^{-1}$ ) and the sludge had a much lower ash content of $7 \%$ compared to $32 \%$ at $20{ }^{\circ} \mathrm{C}$. At $35{ }^{\circ} \mathrm{C}$, suspended solid concentration slightly decreased to $3.6 \mathrm{gVss}^{-1}$, and the ash content remained low $(6 \%)$. 

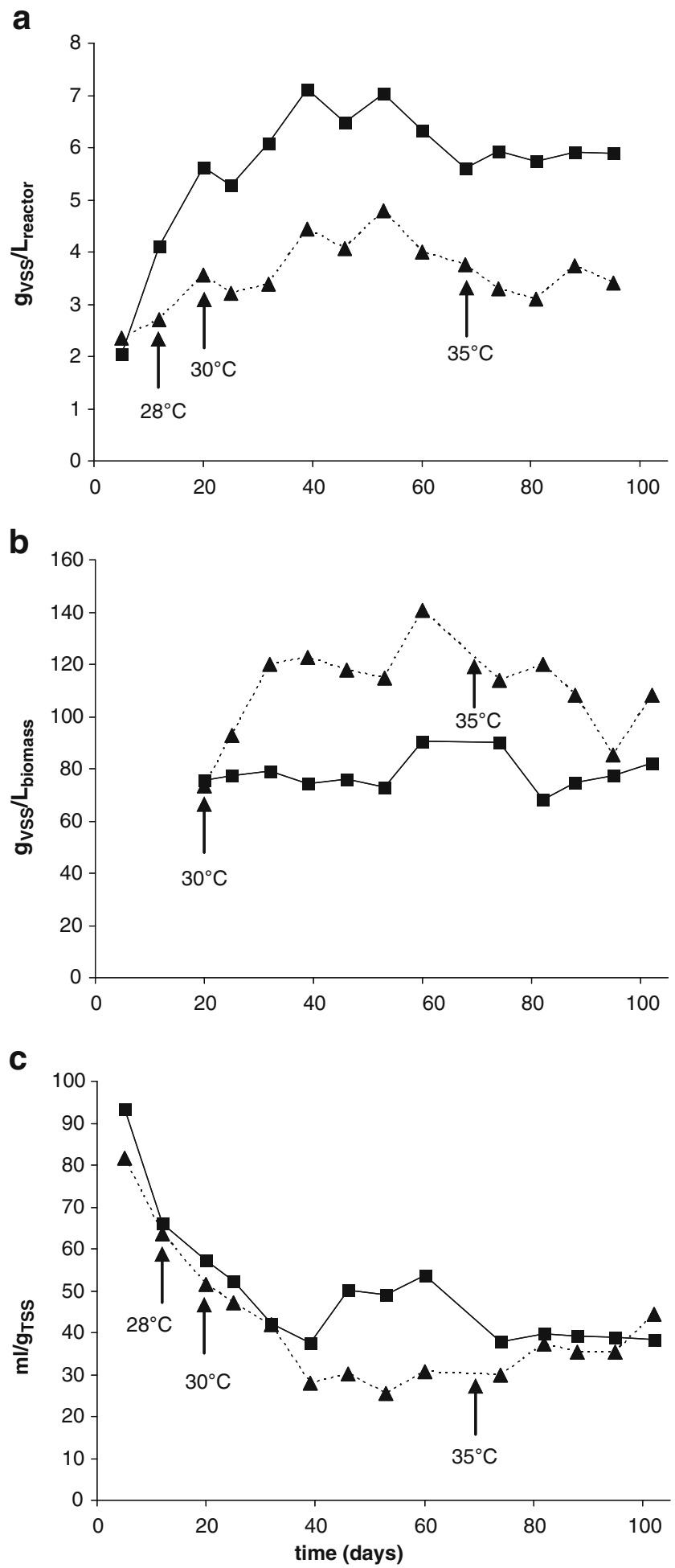

Fig. 1 Properties of the granules of the reactor operated at $20{ }^{\circ} \mathrm{C}$ (filled square with connecting line) and the stepwise temperature increase reactor (filled triangle with dashed connecting line) during the secondary stage experiment: dry weight (a), density of the granules (b), and sludge volume index $\mathrm{SVI}_{8}(\mathbf{c})$
The morphology properties of the granules were only slightly different at different temperatures. The average diameter of the granules was $0.92 \mathrm{~mm}$ at $20{ }^{\circ} \mathrm{C}$, while it decreased to 0.76 and $0.74 \mathrm{~mm}$ at $30{ }^{\circ} \mathrm{C}$ and $35{ }^{\circ} \mathrm{C}$, respectively. A similar particle size distribution was observed for the three different temperatures. In all cases, the measured diameter of $99 \%$ of the granules was below $3 \mathrm{~mm}$. Approximately $80 \%$ of the granules were rather small with a diameter $<1 \mathrm{~mm}$. At $35^{\circ} \mathrm{C}$, part of the biomass was constituted of small well-settling particles which were not taken into account in this calculation due to their small size $(<0.1 \mathrm{~mm})$.

At $20{ }^{\circ} \mathrm{C}$, the estimated sludge residence time was fluctuating between 25 and 50 days, whereas at $30^{\circ} \mathrm{C}$ and $35^{\circ} \mathrm{C}$, it was quite constant with values of 20 and 15 days, respectively. The measured effluent biomass concentration was in the range of 0.07 to $0.14 \mathrm{~g}_{\mathrm{TSS}} \mathrm{L}^{-1}$, regardless of the operation temperature.

Nutrient removal performances

\section{First-stage experiment}

Based on influent and effluent measurements, COD was always completely removed from the artificial wastewater. No significant nitrification and almost no phosphate removal were observed. Cycle profile measurements showed that acetate was consumed only to a small extent (18-25\%) during the anaerobic feeding period in both reactors. No phosphorous release was measured during this period either. Acetate was rapidly consumed during the first $20 \mathrm{~min}$ of the aeration period, and during the entire aerobic phase, some ammonium and phosphate were removed, probably due to assimilation into biomass.

\section{Second-stage experiment}

Similar to the first-stage experiment, COD was present as acetate was completely removed during a cycle. However, at $20^{\circ} \mathrm{C}$, the consumption during the anaerobic and aerobic periods started to change after approximately 3 weeks of operation with acetate being consumed already during the anaerobic feeding period. At the same time, phosphate was released. During the aerobic cycle period the remaining acetate was consumed and overall significant amounts of phosphate were removed. This biological phosphorous removal steadily increased until weeks 6 to 7 when it leveled off and remained constant with an average phosphate removal rate of $63 \%$ (Table 1 ). From this time point on nearly all acetate was consumed during the anaerobic period (Fig. 2a). The ratio between the moles of phosphorous released, and the moles of carbon taken up were of $0.31 \mathrm{P}-\mathrm{mol} \mathrm{C}-\mathrm{mol}^{-1}$. Interestingly, the ash content 
Table 1 Phosphorus and nitrogen removal efficiencies during the second-stage experiment

\begin{tabular}{llll}
\hline & $20{ }^{\circ} \mathrm{C}$ & $30{ }^{\circ} \mathrm{C}$ & $35{ }^{\circ} \mathrm{C}$ \\
\hline P-removal efficiency (\%) & 63 & 8 & 0 \\
Nitrification efficiency (\%) & 0 & 85 & 88 \\
Nitrogen removed per cycle (\%) & NA & 39 & 20 \\
\hline
\end{tabular}

The values presented are the average of several analyses performed at different weeks

$N A$ not applicable due to absence of nitrification

of the sludge started to increase from week 3 onward and reached rather high values of $35 \%$ of TSS after more than 3 months of operation. Surprisingly and despite operating the reactor for more than 160 days, no nitrification was observed and the little ammonium removed was probably only due to assimilation by biomass formation (Fig. 2b).

Reactor A that was first operated at $25{ }^{\circ} \mathrm{C}$ for 12 days followed by an operation at $28^{\circ} \mathrm{C}$ for 9 days before being operated at $30{ }^{\circ} \mathrm{C}$ showed quite different nutrient removal performances. Acetate was consumed at most for about $60 \%$ during the anaerobic period, the remaining acetate being quickly consumed during the first $15 \mathrm{~min}$ of the aeration period (Fig. 2c). Phosphorus removal was low ( $8 \%$; Fig. 2c) and the ash content of the sludge remained low at $6-7 \%$ in average. Nitrification on the contrary started to occur after 3 weeks of operation and reached up to $85 \%$ under quasi-steady state conditions (Table 1). The major product was nitrite but also some nitrate was produced (Fig. 2d).

At $35{ }^{\circ} \mathrm{C}$ nitrification remained similar to $30^{\circ} \mathrm{C}$ (Table 1 and Fig. 2f). About $25 \%$ of the acetate was consumed during the anaerobic phase, and phosphate removal was nearly absent (Fig. 2e). Similar to the operation temperature of $30{ }^{\circ} \mathrm{C}$, the remaining acetate was quickly consumed during the first $15 \mathrm{~min}$ of the aeration period.

Evolution of microbial communities

\section{First-stage experiment}

The T-RFLP profile of the microbial community after 2 days of the start-up of the reactor was already dramatically different from the inoculation sludge (Fig. 3a, insert). The evolution of the microbial community structure was very similar for both reactor operation temperatures until day 28 . After the first 4 weeks of operation, the microbial community structure of reactor $\mathrm{B}$ continued to evolve whereas the one of reactor A remained rather stable (Fig. 3a). At $20{ }^{\circ} \mathrm{C}$, the Shannon diversity index increased from 0.42 on day 2 (2.05 for inoculum sludge) to 1.92 on day 66 .
In order to get indications on the predominant operational taxonomic units (OTU) present, the OTUs whose peaks exceeded $3 \%$ of the total T-RF peak surface were analyzed in more detail (Fig. 4). These OTUs accounted for $92.0 \pm 4.9 \%$ and $90.3 \pm 5.1 \%$ of the total T-RF peak area in the case of the $30{ }^{\circ} \mathrm{C}$ and $20{ }^{\circ} \mathrm{C}$ reactor, respectively. After normalization to $100 \%$, seven OTUs accounted for $83.8 \pm$ $8.1 \%$ in the $30{ }^{\circ} \mathrm{C}$ reactor and six OTUs for $85.8 \pm 7.1 \%$ in the $20{ }^{\circ} \mathrm{C}$ reactor, respectively. Five of these predominant OTUs were found in both reactors and their T-RFs had a length of $195,208,215,224$, and 250 nucleotides. The unspecified OTUs summarized under "others" (Fig. 4) include OTUs that were only observed with an abundance of $>3 \%$ up to three times randomly during reactor operation.

OTU 250 was predominant short after reactor start-up, stayed predominant at $20{ }^{\circ} \mathrm{C}$ during the first 2 weeks but lost predominance rapidly at $30{ }^{\circ} \mathrm{C}$. OTU 195 became predominant in both reactors with a certain time lag at $20{ }^{\circ} \mathrm{C}$. Abundance of OTU 195 fluctuated during reactor operation but this OTU accounted in many samples for at least $50 \%$ of the total peak area. OTU 208 was quite abundant (8.2-35.6\%) during the first 4 weeks at $30{ }^{\circ} \mathrm{C}$ but was much less abundant at $20{ }^{\circ} \mathrm{C}(5.4-12.1 \%)$. OTU 224 on the other hand became abundant from day 24 on at $20^{\circ} \mathrm{C}$ and accounted for $21.2 \%$ to $48.0 \%$ of total peak area during the last 4 weeks of reactor operation and was much less abundant at $30{ }^{\circ} \mathrm{C}$.

\section{Second-stage experiment}

The microbial communities evolved rather similar in reactor B operated at $20{ }^{\circ} \mathrm{C}$ and reactor A operated first at $25{ }^{\circ} \mathrm{C}$ (Fig. 3b). However, when increasing the temperature to $28{ }^{\circ} \mathrm{C}$ for a short period ( 9 days) and in the following to $30{ }^{\circ} \mathrm{C}$ for a longer period (48 days), the composition of reactor A microbial community shifted away from reactor $\mathrm{B}$ samples expressing clearly different community structures at higher temperatures. After an additional increase to $35^{\circ} \mathrm{C}$, the rather stable community structure obtained at $30{ }^{\circ} \mathrm{C}$ evolved again. The Ruzicka distance for samples collected at the same day but at different temperatures was 0.5 between samples at $20^{\circ} \mathrm{C}$ and $28^{\circ} \mathrm{C}, 0.7$ between samples at $20^{\circ} \mathrm{C}$ and $30^{\circ} \mathrm{C}$, and 0.8 between samples collected at $20^{\circ} \mathrm{C}$ and $35^{\circ} \mathrm{C}$, respectively, confirming that the dissimilarities between the different microbial communities increased with increasing temperature.

The Shannon diversity index was approximately 1.8 for all samples of reactor $B$ as well as for the samples of reactor A with an operation temperature of up to $30{ }^{\circ} \mathrm{C}$. The diversity started to decrease after temperature increase to $35{ }^{\circ} \mathrm{C}$ with a final diversity index of only about 1.0 . These trends were also confirmed with the Ruzicka and Jaccard distances calculated for all samples in relation to their 


\section{a}

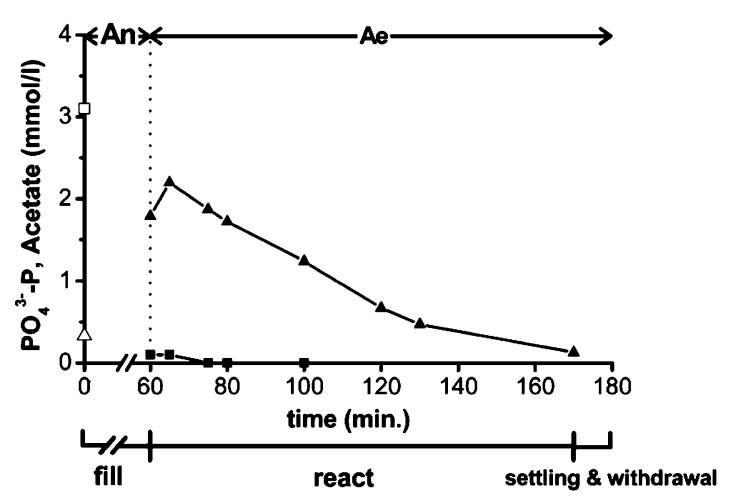

C

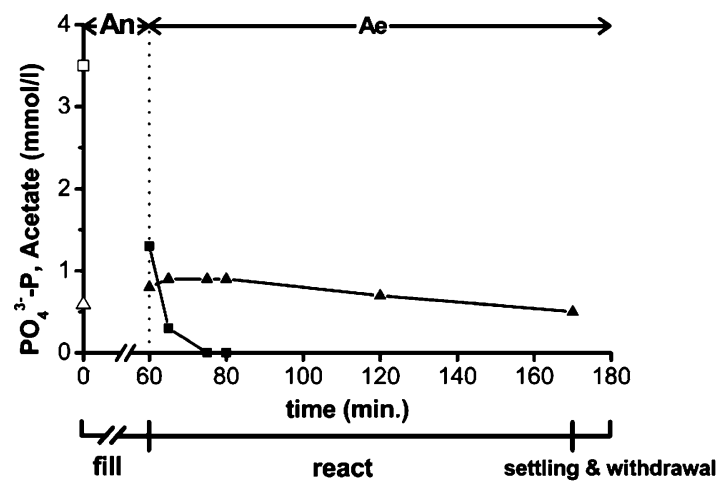

e

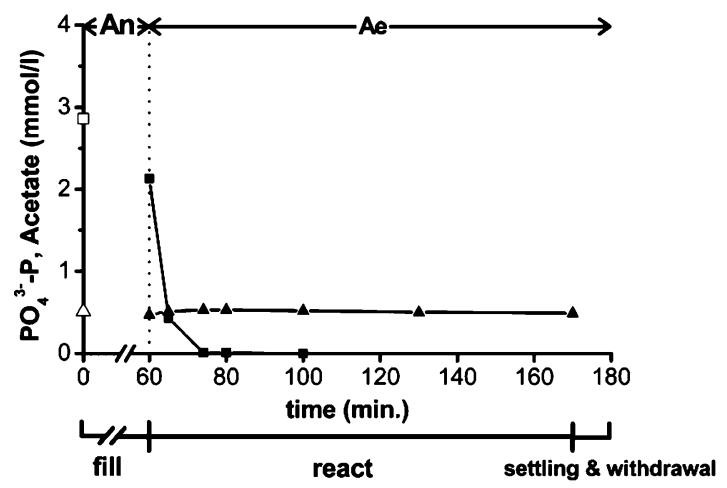

Fig. 2 Typical concentration patterns of acetate (filled square), $\mathrm{PO}_{4}{ }^{3-}-\mathrm{P}$ (filled triangles), $\mathrm{NH}_{4}{ }^{+}-\mathrm{N}$ (filled circle), $\mathrm{NO}_{3}{ }^{-} \mathrm{-N}$ (filled diamond), and $\mathrm{NO}_{2}^{-}-\mathrm{N}$ (inverted filled triangle) in millimolar in a cycle during the second-stage experiment. a and b $20^{\circ} \mathrm{C}$. $\mathbf{c}$ and d $30^{\circ} \mathrm{C}$. e and f $35^{\circ} \mathrm{C}$.

preceding sample. After initially high values around 0.8 , they dropped and fluctuated between 0.2 and 0.4 at $20{ }^{\circ} \mathrm{C}$ as well as up to $30^{\circ} \mathrm{C}$. They increased rapidly to 0.65 after temperature increased to $35^{\circ} \mathrm{C}$.

The predominant OTUs were also analyzed in the second-stage experiment (Fig. 5). These OTUs accounted for $71.9 \pm 5.7 \%$ and $76.0 \pm 4.1 \%$ of the total T-RF peak surface in the case of increasing operation temperature reactor and the $20{ }^{\circ} \mathrm{C}$ reactor, respectively. After normalization to $100 \%$, seven OTUs accounted for $85.4 \pm 9.5 \%$ and

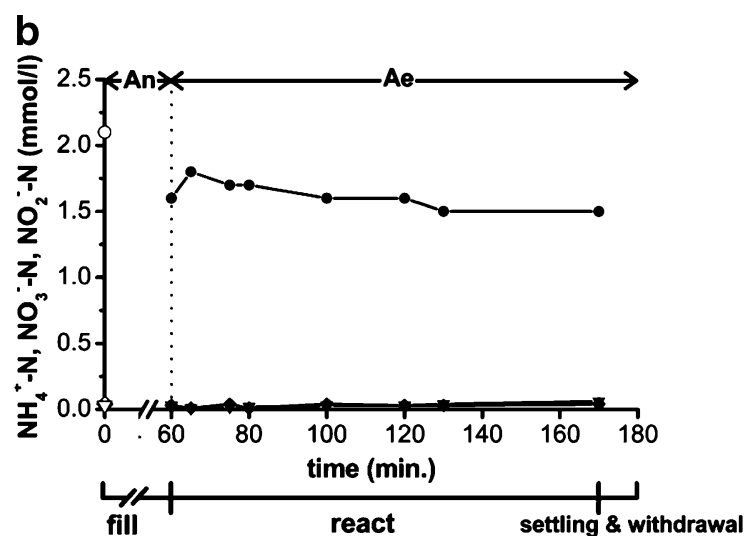

d
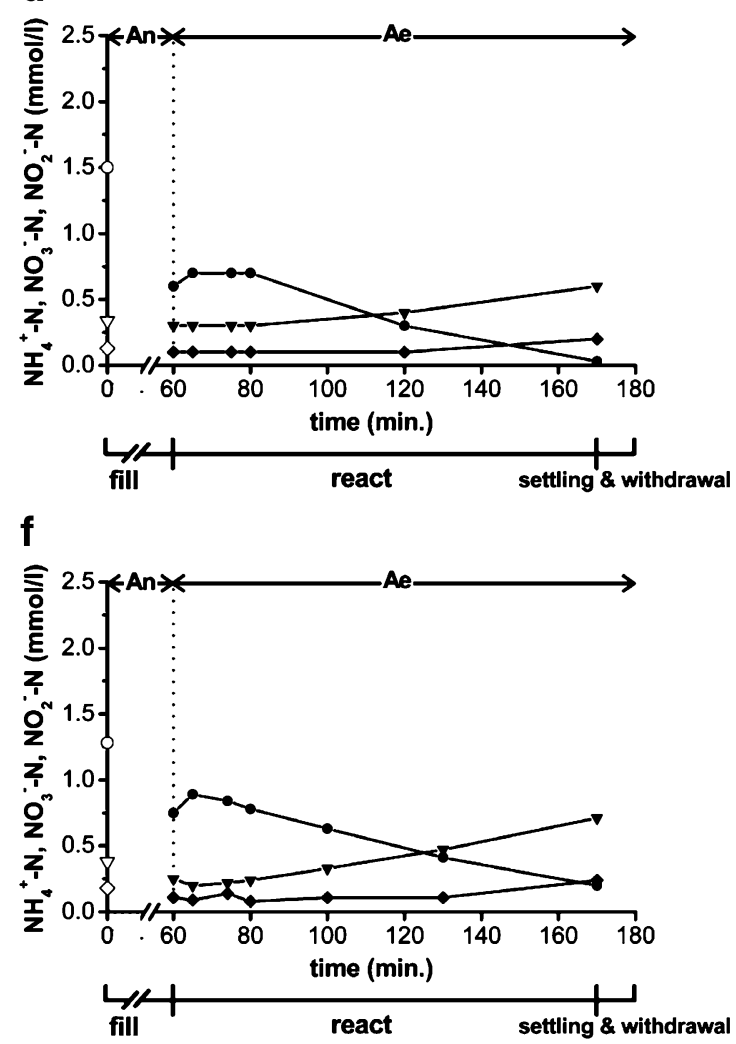

The open symbols on the $y$-axis indicate the concentrations after anaerobic feeding at the start of the aeration period if no process would have influenced these compounds during feeding

$90.3 \pm 4.3 \%$ in the two reactors, respectively. Six of these seven OTUs with a T-RF length of 193, 195, 214, 224, 239, and 289 nucleotides were found in both reactors. OTU 216 was only observed in reactor A, whereas OTU 185 was exclusively found in the communities of reactor $\mathrm{B}$. The latter started to be present in reactor B after approximately 2 weeks of operation, accounted for $6.6 \pm 2.3 \%$ of the total peak area, and was never observed in reactor A. OTU 193 was present in both reactors, accounted for $9.5 \pm 3.2 \%$ of total peak area of reactor B community and disappeared 
a

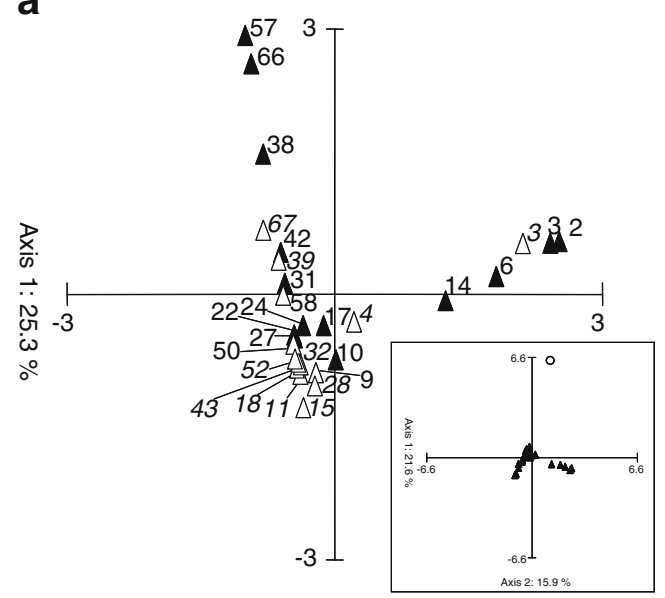

Axis 2: $17.1 \%$

b

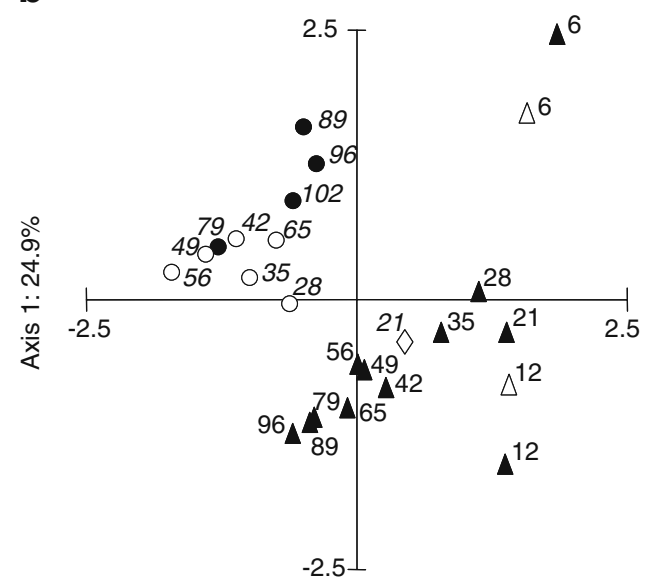

Axis 2: $19.1 \%$

Fig. 3 Correspondence analysis (CA) of microbial communities present in the two BC-SBRs. The points represent the bacterial community structure according to T-RFLP analysis. a First-stage experiment with two reactors operated at constant temperatures; closed triangles, $20{ }^{\circ} \mathrm{C}$ reactor; open triangles, $30{ }^{\circ} \mathrm{C}$ reactor; and insert, CA of all samples (closed triangles) plus the inoculum (open circle). b Second-stage experiment with one reactor operated at $20^{\circ} \mathrm{C}$ and the other at increasing temperature; closed triangles, $20{ }^{\circ} \mathrm{C}$ reactor; open triangles, $25{ }^{\circ} \mathrm{C}$; open diamond, $28{ }^{\circ} \mathrm{C}$; open circles, $30{ }^{\circ} \mathrm{C}$; and closed circles, $35{ }^{\circ} \mathrm{C}$. The numbers beside the points indicate the day of sampling, the italic ones in a for the samples of the first stage $30{ }^{\circ} \mathrm{C}$ reactor and in $\mathbf{b}$ for the second-stage reactor operated at increasing temperature

rapidly in reactor A when operated at $30^{\circ} \mathrm{C}$. OTU 195 was predominant short after start-up in both reactors (approximately $50 \%$ of total peak area). It decreased in reactor B and was absent after day 65. In reactor A, this OTU was almost always present and became predominant again at $35{ }^{\circ} \mathrm{C}$ (approximately $20 \%$ of total peak area).

OTU 214 appeared in both reactors after 6 weeks of operation (day 42), gained importance in reactor B finally accounting for $28 \%$ of the total peak area, and disappeared in reactor $\mathrm{A}$ after increase of the temperature from $30{ }^{\circ} \mathrm{C}$ to $35{ }^{\circ} \mathrm{C}$. OTU 224 accounted in reactor B for $18.9 \pm 8.5 \%$ of the total peak surface with decreasing trend from week 7 to the end of the experiment. In reactor A, OTU 224 was predominant after 2 weeks of operation (approximately $28 \%$ ) but the peak surface decreased constantly being absent during the last 2 weeks of operation. OTU 239 was predominant in reactor A from week 4 onward with a peak surface of $26.7 \pm 5.4 \%$. This OTU appeared somewhat later in reactor B but accounted at the end for $18.6 \pm 1.4 \%$ of the total peak area. Whereas OTU 289 was constantly present in the reactor B community with an average peak area of $7.8 \pm 2.7 \%$, it was present in reactor $\mathrm{A}$ at similar abundances of $8.4 \pm 2.0 \%$ up to $30{ }^{\circ} \mathrm{C}$. OTU 289 became predominant at $35{ }^{\circ} \mathrm{C}$ with peak areas of $20.4 \pm 2.7 \%$.

\section{Identification of predominant OTUs}

The identification of predominant OTUs was realized through cloning and sequencing of partial 16S rRNA gene sequences. Cloned PCR products were first analyzed by T-RFLP, and clones showing a T-RF identified as predominant in the electropherograms were sequenced and analyzed. Between 2 and 14 clones were analyzed for each OTU, only for OTUs 215 and 216, there was only one clone available (Table 2). For five OTUs $(185,195,224$, $239,250)$, the identification was not straightforward, possibly indicating that the OTU was composed of more than one population. The presence of two populations in one OTU was however only observed in three cases, e.g., for OTU 185 in reactor A of the first-stage experiment, for OTU 195 in reactor B of the first-stage experiment, and for OTU 250 in reactor B. In other two cases, one population was either only detected in one of the two reactors operated in parallel or only during one stage of the two experimentation periods.

Most of the obtained sequences affiliated with clones and bacteria which have been isolated themselves from wastewater treatment systems, either laboratory or full scale installations, and often also from microbial communities performing EBPR or at least undergoing anaerobic-aerobic cycles. A striking feature was that almost all OTUs were affiliated with the phylum Proteobacteria. Members of bacterial guilds normally encountered in EBPR such as PAO and GAO were identified within different OTUs. Putative GAO were identified within OTU 185 and 239, putative PAO within OTU 214. Both GAO and PAO were mainly detected in the second-stage experiment, with the exception of one clone with a T-RF of 185 nucleotides that has been isolated from a first-stage sludge sample from reactor A. The clone that fell within OTU 216 affiliated with isolate Is 32 that has been identified as a strain of the aerobic ammonium-oxidizing genus Nitrosomonas. 
Fig. 4 Relative abundance of different OTUs detected in granular sludge samples taken after different times of operation during the first-stage experiment according to T-RFLP analysis. a $\mathrm{BC}-\mathrm{SBR}$ where the temperature was maintained at $30^{\circ} \mathrm{C}$. b BCSBR where the temperature was kept constant at $20{ }^{\circ} \mathrm{C}$. Only those OTUs that accounted at least once for $>3.0 \%$ of the total peak surface are represented, and the whole was normalized to $100 \%$ ignoring the peak surface of the minor OTUs. In the category "others" are summarized OTUs that did not have a clear pattern and were detected only one to three times in the samples analyzed. Indicated on top of each bar is the duration of the sedimentation phase in minutes
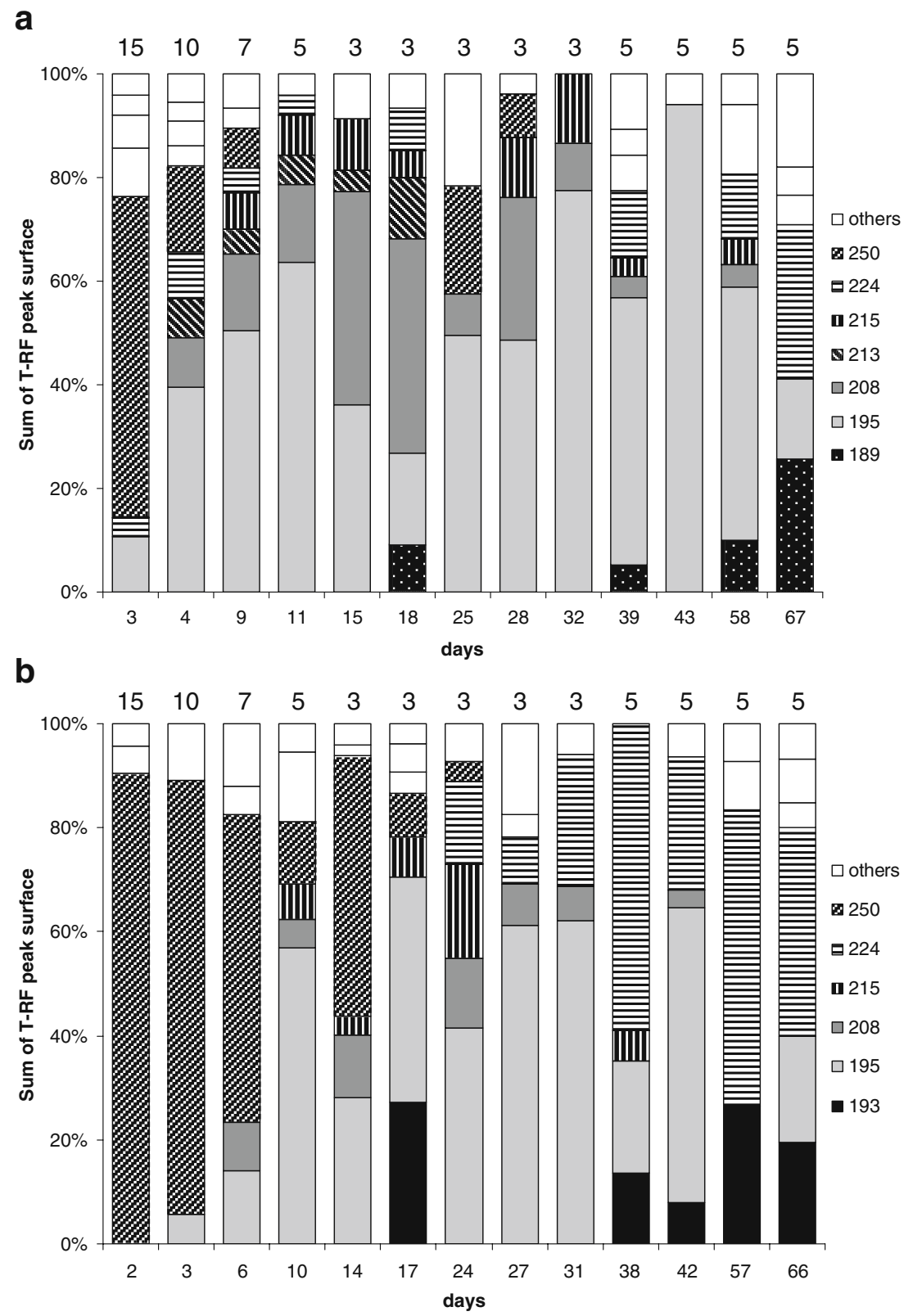

\section{Discussion}

The major goal of this study was to evaluate the influence of temperature ranging from $20{ }^{\circ} \mathrm{C}$ to $35{ }^{\circ} \mathrm{C}$ on the formation and stability, on nutrient removal, and on the microbial community composition of aerobic granular sludge. With the inoculum sludge used, start-up at $30{ }^{\circ} \mathrm{C}$ and obtaining stable aerobic granular sludge failed. The observed fluffy granule structure and the presence of filamentous bacteria as shown by molecular analysis indicated that at an initial temperature of $30{ }^{\circ} \mathrm{C}$ these bacterial populations had a selective advantage over populations promoting the formation of smooth fastsettling granules and hindered the formation of stable aerobic granular sludge. It was only possible to obtain stable aerobic granular sludge at $30{ }^{\circ} \mathrm{C}$ and $35{ }^{\circ} \mathrm{C}$ when aerobic granular sludge cultivated in a BC-SBR operated at $20{ }^{\circ} \mathrm{C}$ was used as seed sludge and temperature was stepwise increased. A similar observation has been made in a study investigating the feasibility of aerobic granular sludge technology at low temperatures (de Kreuk et al. 2005b). Start-up at $8{ }^{\circ} \mathrm{C}$ has failed whereas lowering temperature after a start-up at $20{ }^{\circ} \mathrm{C}$ succeeded in an operational system at $8{ }^{\circ} \mathrm{C}$.

The properties of the granular sludge obtained at $20^{\circ} \mathrm{C}$, $30{ }^{\circ} \mathrm{C}$, and $35{ }^{\circ} \mathrm{C}$ were quite similar and comparable with sludge properties reported in previous studies. Granules had a similar diameter as the ones obtained in a sequencing 
Fig. 5 Relative abundance of different OTUs detected in granular sludge samples taken after different times of operation during the second-stage experiment according to T-RFLP analysis. a BC-SBR where the temperature was stepwise increased. b BC-SBR where the temperature was kept constant at $20{ }^{\circ} \mathrm{C}$. The inoculum for both reactors was aerobic granular sludge obtained during the firststage experiment with a BCSBR operated at $20^{\circ} \mathrm{C}$. Only those OTUs that accounted at least once for $>3.0 \%$ of the total peak surface are represented, and the whole was normalized to $100 \%$ ignoring the peak surface of the minor OTUs. In the category "others" are summarized OTUs that did not have a clear pattern and were detected only one to three times in the samples analyzed. $E A$ and $E B$ represents the analysis of effluent biomass at day 96. $W G$ represents the analysis of white granules that were separated from the rest by visual screening and selection

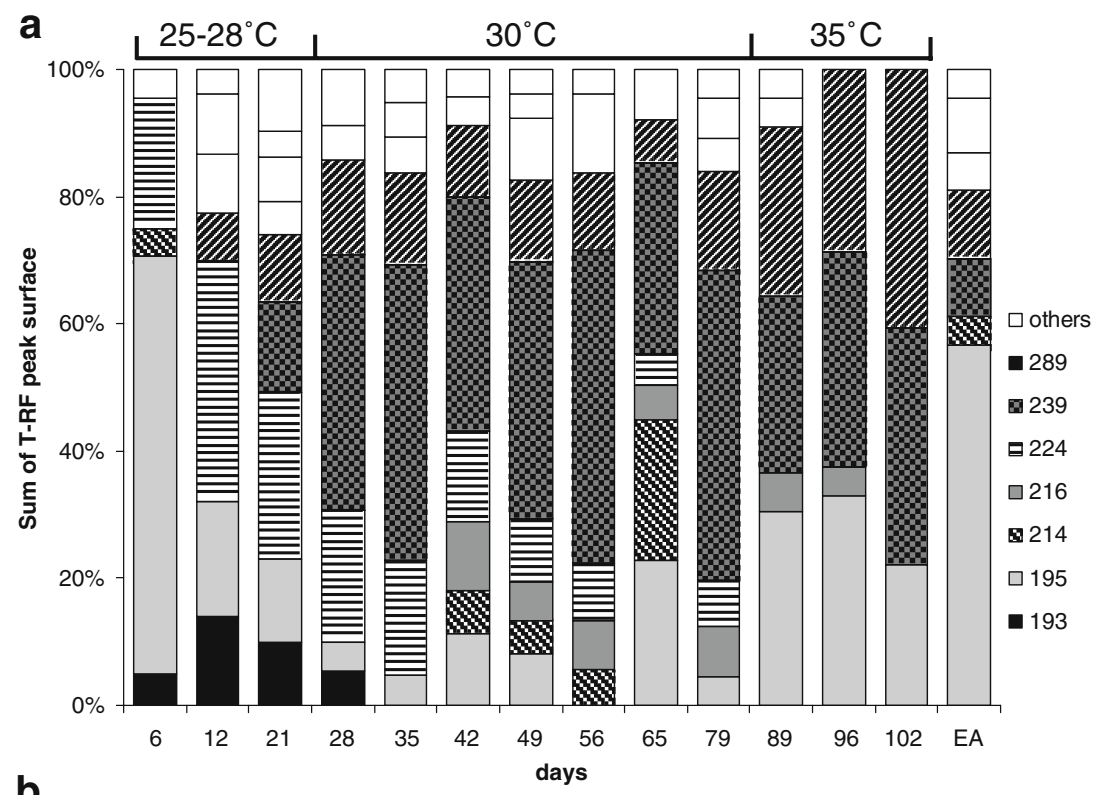

b

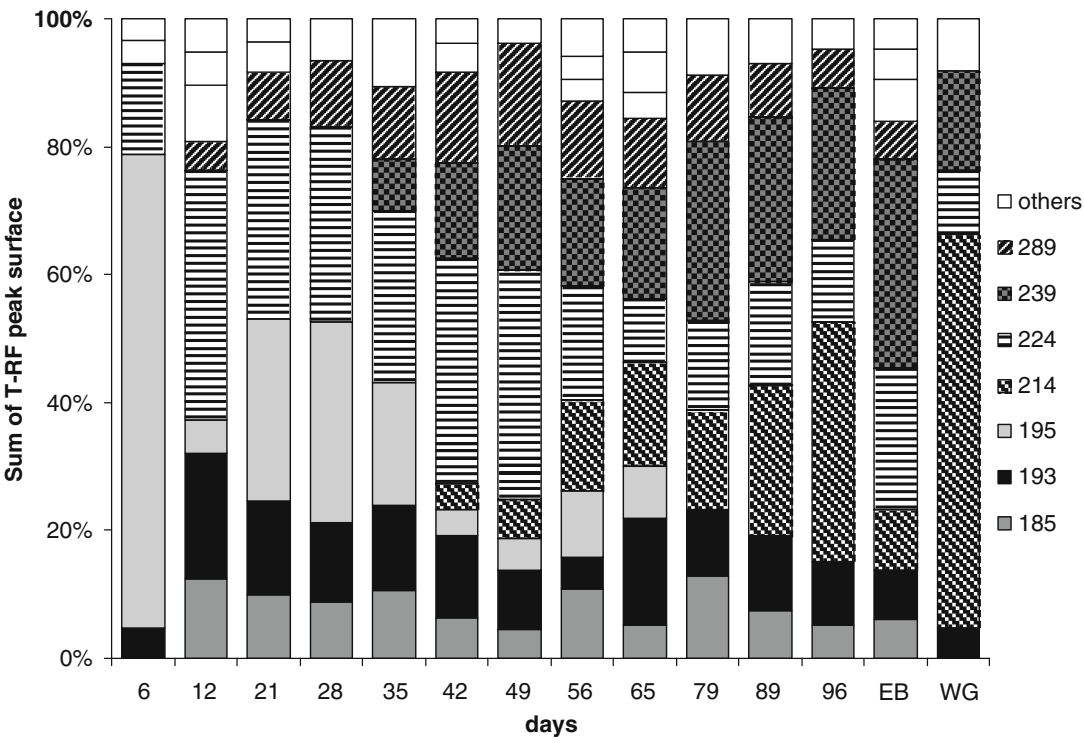

batch airlift reactor with slow anaerobic feeding (de Kreuk et al. 2005a) but was smaller than the granule diameter of sludge obtained with aerobic pulse feeding (Beun et al. 2002). Biomass concentration in the reactor and $\mathrm{SVI}_{8}$ were also comparable with the values reported for a sequencing airlift reactor (de Kreuk et al. 2005a) indicating that the reactor configuration has no major influence on these sludge properties. The density of $75 \mathrm{~g}_{\mathrm{vss}} \mathrm{L}_{\text {biomass }}{ }^{-1}$ of $20{ }^{\circ} \mathrm{C}$-sludge was in the same range as the sludge density reported by others (Beun et al. 2002; de Kreuk et al. 2005a). Interestingly, the $30{ }^{\circ} \mathrm{C}-$ and $35{ }^{\circ} \mathrm{C}$-sludge of this study was almost twice as dense $\left(120 \mathrm{~g}_{\mathrm{VSS}} \mathrm{L}_{\text {biomass }}{ }^{-1}\right)$ as $20{ }^{\circ} \mathrm{C}$-sludge. The start-up time of 3 weeks necessary to obtain granular sludge was rather long compared with a sequencing batch airlift reactor with aerobic pulse feeding
(Beun et al. 2002) but was very similar with sequencing reactors operated with slow anaerobic feeding independent whether it was an airlift or bubble column reactor (de Kreuk and van Loosdrecht 2004; de Kreuk et al. 2005b).

Although the inoculation sludge was taken from a WWTP performing biological nitrogen as well as phosphorous removal, the time needed until EBPR was observed was very long. No significant phosphorous removal other than assimilation by biomass formation was observed during the first-stage experiment, and EBPR only was significant after additional 6 weeks of operation of the second-stage reactors. Acclimatization of activated sludge to alternating anaerobic-aerobic conditions resulting in enrichment of PAO has been shown to require 40-100 days (Kortstee et al. 1994) and start-up failures and process 


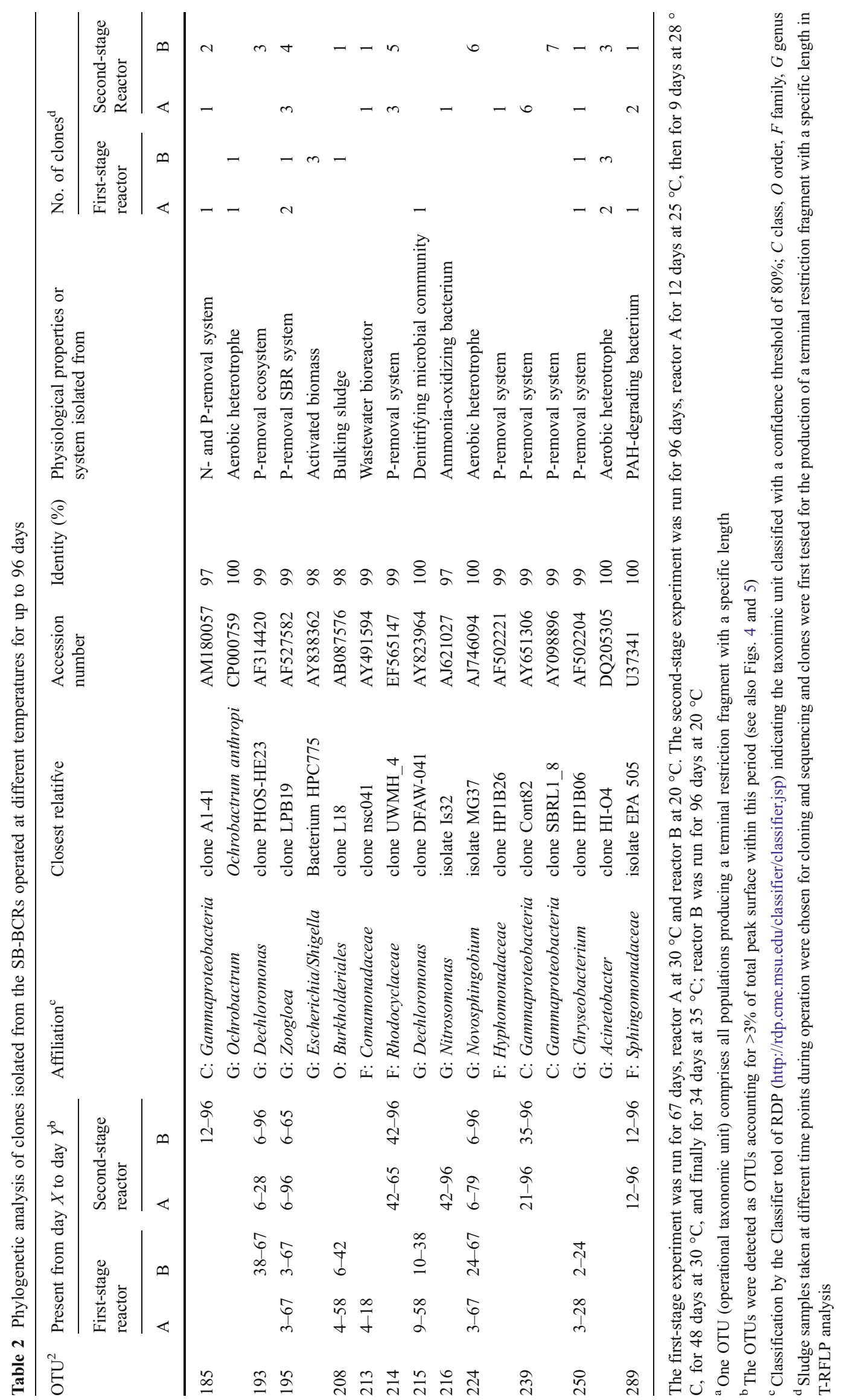


breakdowns have been reported (Cech and Hartman 1993; Satoh et al. 1994; Bond et al. 1998). However, the inoculum sludge used here has already been acclimatized and therefore, only the rigorous change of conditions such as the artificial wastewater with very reduced composition complexity and the mode of operation, SBR versus traditional activated sludge process, might explain the failure of rapid establishment of all nutrient removal properties of the inoculum sludge in the aerobic granular sludge. Besides EBPR, also nitrification was observed only in a later stage of the second-stage experiment, and this was, even more surprisingly, only at $30{ }^{\circ} \mathrm{C}$. Similar long periods for establishment of biological nitrogen and phosphorous removal have been reported earlier despite the use of well-adapted activated sludge (de Kreuk et al. 2005a). Biological phosphorous removal has reached $95 \%$ removal efficiency after 65 days of reactor operation and significant nitrification, initially inhibited by the addition of allylthiourea for 52 days, has been observed only about 100 days after stopping addition of allylthiourea.

Nutrient removal performances were quite different at the different temperatures investigated. EBPR followed the same trends as observed in other studies comparing different treatment temperatures (Erdal et al. 2003; Panswad et al. 2003; Whang and Park 2006; Lopez-Vazquez et al. 2007). These studies have shown that at $20{ }^{\circ} \mathrm{C}$ and below, PAO were predominant and thus able outcompeting GAO that deteriorate the desired nutrient elimination process. At $30^{\circ} \mathrm{C}$, EBPR was less effective due to competitive advantages of GAO at this mesophilic temperature. In the present study, EBPR was very inefficient at $30{ }^{\circ} \mathrm{C}$ with only $8 \%$ phosphorous removal and even completely absent at $35^{\circ} \mathrm{C}$.

The detailed analysis of the composition and the dynamics of the microbial communities present in the two experimental stages clearly showed that many of the different phenomena observed concerning granule formation and nutrient removal were probably due to the presence of specific predominant OTUs. Shortly after start-up, the remaining sludge was dominated by OTU 250 composed of mainly Acinetobacter-affiliated populations and to lesser extends by Chryseobacterium-affiliated populations (Fig. 4, Table 2). After a few more days where sedimentation time was reduced from 15 to $5 \mathrm{~min}$, the biomass was mainly containing OTU 195 in both reactors, an OTU that was also composed of at least two populations, a betaproteobacterial Zoogloea-affiliated population and one that affiliated with a gammaproteobacterial clone isolated from activated biomass. Zoogloea spp. are known to be typically encountered in activated sludge flocs gluing together the different organisms present in these microbial flocs (Rosselló-Mora et al. 1995). The predominance of OTU 195 fluctuated but remained quite important at $30{ }^{\circ} \mathrm{C}$ and lost predominance at $20{ }^{\circ} \mathrm{C}$.
Besides OTU 195, other OTUs such as OTU 208, OTU 215 , and OTU 224 appeared in the sludge of the first-stage experiment selected by short sedimentation periods of only 3 to $5 \mathrm{~min}$. At $30{ }^{\circ} \mathrm{C}$ where fluffy granules were observed, the microbial community contained significant parts of OTU 208 whose clones affiliated with clones that have been identified as Sphaerotilus spp. and Leptothrix spp., both filamentous bacteria observed in bulking sludge (Martins et al. 2004). OTU 208 was also observed at $20{ }^{\circ} \mathrm{C}$ but was much less abundant. Poor long-term stability of aerobic granules has been reviewed recently and growth of filamentous bacteria due to increase of temperature has been identified as one of the causes of this undesired phenomenon (Liu and Liu 2006).

OTU 224 containing mainly Sphingomonadaceae-affiliated populations became quite abundant at $20^{\circ} \mathrm{C}$ when the sludge biomass was composed primarily of smooth granules ( $>24$ days of operation). This OTU was only periodically observed at $30^{\circ} \mathrm{C}$ and was much less abundant. In addition to OTU 224, OTU 193 affiliated with the genus Dechloromonas became an important OTU in the smooth granular sludge biomass at $20{ }^{\circ} \mathrm{C}$. The granular sludge biomass that developed at $20{ }^{\circ} \mathrm{C}$ and that had similar characteristics as granular sludge described in other studies did not contain obvious PAO and GAO that should normally be enriched by the operation mode applied and that have been proposed as a mean for improving aerobic granular sludge stability (de Kreuk and van Loosdrecht 2004).

The composition of the granular sludge after 1 week of operation in the second stage was quite similar at $20^{\circ} \mathrm{C}$ and $25^{\circ} \mathrm{C}$ and comparable with the inoculum sludge taken from the first stage $20{ }^{\circ} \mathrm{C}$ reactor. The main difference with the inoculum sludge was that the Zoogloea-affiliated OTU 195 was again the predominant one after this short period of reactor start-up. This OTU reduced in abundance and disappeared at $20{ }^{\circ} \mathrm{C}$ but became an abundant OTU in reactor A when operated at $35{ }^{\circ} \mathrm{C}$. The two Shingomonadaceae-affiliated OTUs 224 and 289 were observed in both reactors but exhibited different dynamics. OTU 224 was always present abundantly at $20{ }^{\circ} \mathrm{C}$ but abundance decreased at higher temperatures in reactor A. OTU 289 was a minor OTU at $20{ }^{\circ} \mathrm{C}$ but became a predominant one at $35{ }^{\circ} \mathrm{C}$. It seems, however, that overall such Sphingomonadaceaeaffiliated OTUs had an important function in granular structure and stability. Although all clones representing these OTUs affiliated with Alphaproteobacteria, they were not closely related with putative GAO of the same phylum (Meyer et al. 2006). This does however not exclude that the Sphingomonadaceae-affiliated clones observed here do not have a GAO-like metabolism.

Two different OTUs, OTU 185 and OTU 239, represent putative GAO belonging to the class Gammaproteobacteria and tentatively named "Candidatus Competibacter phos- 
phatis" (Crocetti et al. 2002). OTU 185 was only observed at $20{ }^{\circ} \mathrm{C}$, whereas OTU 239 was present at all temperatures. The latter became a very predominant OTU at $30{ }^{\circ} \mathrm{C}$ and $35{ }^{\circ} \mathrm{C}$ which is in accordance with previous findings that higher temperatures allow GAO to outcompete PAO (Erdal et al. 2003; Panswad et al. 2003; Whang and Park 2006; Lopez-Vazquez et al. 2007).

OTU 214 that contained mainly the Rhodocyclaceaeaffiliated PAO, tentatively named "Candidatus Accumulibacter phosphatis" (Hesselmann et al. 1999), was observed from week 6 onward when also EBPR activity started to be observed at $20{ }^{\circ} \mathrm{C}$ and $30{ }^{\circ} \mathrm{C}$. It became a quite abundant OTU at $20{ }^{\circ} \mathrm{C}$ which is in agreement with the increasing EBPR activity observed in this reactor. The same OTU disappeared at $35{ }^{\circ} \mathrm{C}$ where no EBPR activity was observed anymore. Similar agreement between reactor performance and the corresponding OTU present in the sludge sample was observed for nitrification activity. OTU 216 that was a Nitrosomonas-affiliated OTU was only observed at $30{ }^{\circ} \mathrm{C}$ and $35{ }^{\circ} \mathrm{C}$ but not at $20^{\circ} \mathrm{C}$ where no nitrification occurred.

The goal of the molecular study of the microbial community composition and dynamics was to characterize the diversity of predominant OTUs and the composition of the latter. The composition of the sludge microbial communities was not very complex, possibly as a response of the use of a low-complexity artificial wastewater. However, all clone sequences obtained affiliated with clones or isolates that have been obtained from activated sludge or SBR wastewater treatment systems. Quite frequently, they have even been obtained from systems performing EBPR and/or nitrogen removal. Since these clones and isolates have been obtained from sludge flocs, it can be concluded that reactor operation resulting in aerobic granular sludge formation is not selecting specific bacteria forming these structures but is forming microbial granules composed of the same bacteria that form flocs under other conditions. The $20{ }^{\circ} \mathrm{C}$ reactor of the firststage experiment showed in addition that it may not be a prerequisite to contain GAO or PAO in order to get smooth and stable aerobic granules.

Acknowledgments The authors thank Marc Deront and Jean-Pierre Kradolfer for the excellent technical assistance in the reactor construction and operation, respectively.

\section{References}

Altschul SF, Madden TL, Schäffer AA, Zhang J, Zhang Z, Miller W, Lipman DJ (1997) Gapped BLAST and PSI-BLAST: a new generation of protein database search programs. Nucleic Acids Res 25:3389-3402

Beun JJ, Heijnen JJ, van Loosdrecht MCM (2001) N-Removal in a granular sludge sequencing batch airlift reactor. Biotechnol Bioeng 75:82-92
Beun JJ, van Loosdrecht MCM, Heijnen JJ (2002) Aerobic granulation in a sequencing batch airlift reactor. Water Res 36:702-712

Bond PL, Keller J, Blackall LL (1998) Characterisation of enhanced biological phosphorous removal activated sludges with dissimilar phosphorous removal performances. Water Sci Technol 37:567-571

Cech J, Hartman P (1993) Competition between polyphosphate and polysaccharide accumulating bacteria in enhanced biological phosphate removal systems. Water Res 27:1219-1225

Crocetti GR, Hugenholtz P, Bond PL, Schuler A, Keller J, Jenkins D, Blackall LL (2000) Identification of polyphosphate-accumulating organisms and design of $16 \mathrm{~S}$ rRNA-directed probes for their detection and quantitation. Appl Environ Microbiol 66:1175-1182

Crocetti GR, Banfield JF, Keller J, Bond PL, Blackall LL (2002) Glycogen-accumulating organisms in laboratory-scale and fullscale wastewater treatment processes. Microbiol 148:3353-3364

de Bruin LMM, de Kreuk MK, van der Roest HFR, Uijterlinde C, van Loosdrecht MCM (2004) Aerobic granular sludge technology: an alternative to activated sludge? Water Sci Technol 49:1-7

de Kreuk MK, van Loosdrecht MCM (2004) Selection of slow growing organisms as a means for improving aerobic granular sludge stability. Water Sci Technol 49:9-17

de Kreuk MK, Heijnen JJ, van Loosdrecht MCM (2005a) Simultaneous COD, nitrogen, and phosphate removal by aerobic granular sludge. Biotechnol Bioeng 90:761-769

de Kreuk MK, Pronk M, van Loosdrecht MCM (2005b) Formation of aerobic granules and conversion processes in an aerobic granular sludge reactor at moderate and low temperatures. Water Res 39:4476-4484

de Kreuk MK, Kishida N, van Loosdrecht MCM (2007) Aerobic granular sludge - state of the art. Water Sci Technol 55:75-81

Erdal UG, Erdal ZK, Randall CW (2003) The competition between PAOs (phosphorus accumulating organisms) and GAOs (glycogen accumulating organisms) in EBPR (enhanced biological phosphorus removal) systems at different temperatures and the effects on system performance. Water Sci Technol 47:1-8

Filipe CDM, Daigger GT, Grady CPL (2001) pH as a key factor in the competition between glycogen-accumulating organisms and phosphorus-accumulating organisms. Water Environ Res 73:223-232

Hesselmann RPX, Werlen C, Hahn D, van der Meer JR, Zehnder AJB (1999) Enrichment, phylogenetic analysis and detection of a bacterium that performs enhanced biological phosphate removal in activated sludge. Syst Appl Microbiol 22:454-465

Kortstee GJ, Appeldoorn KJ, Bonting CF, van Niel EW, van Veen HW (1994) Biology of polyphosphate-accumulating bacteria involved in enhanced biological phosphorous removal. FEMS Microbiol Rev 15:137-153

Legendre P, Legendre L (1998) Numerical ecology, 2nd English edition edn. Elsevier, Amsterdam

Liu Y, Liu QS (2006) Causes and control of filamentous growth in aerobic granular sludge sequencing batch reactors. Biotechnol Adv 24:115-127

Liu Y, Tay J-H (2004) State of the art of biogranulation technology for wastewater treatment. Biotechnol Adv 22:533-563

Lopez-Vazquez CM, Song YI, Hooijmans CM, Brdjanovic D, Moussa MS, Gijzen HJ, van Loosdrecht MMC (2007) Short-term temperature effects on the anaerobic metabolism of glycogen accumulating organisms. Biotechnol Bioeng 97:483-495

Maidak BL, Olsen GJ, Larsen N, Overbeek R, McCaughey MJ, Woese CR (1996) The Ribosomal Database Project (RDP). Nucleic Acids Res 24:82-85

Martins AMP, Pagilla K, Heijnen JJ, van Loosdrecht MCM (2004) Filamentous bulking sludge - a critical review. Water Res 38:793-817

Meyer RL, Saunders AM, Blackall LL (2006) Putative glycogenaccumulating organisms belonging to the Alphaproteobacteria 
identified through rRNA-based stable isotope probing. Microbiol $152: 419-429$

Morgenroth E, Sherden T, van Loosdrecht MCM, Heijnen JJ, Wilderer PA (1997) Aerobic granular sludge in a sequencing batch reactor. Water Res 31:3191-3194

Mosquera-Corral A, de Kreuk MK, Heijnen JJ, van Loosdrecht MCM (2005) Effects of oxygen concentration on N-removal in an aerobic granular sludge reactor. Water Res 39:2676-2686

Oehmen A, Yuan Z, Blackall LL, Keller J (2004) Short-term effects of carbon source on the competition of polyphosphate accumulating organisms and glycogen accumulating organisms. Water Sci Technol 50:139-144

Panswad T, Doungchai A, Anotai J (2003) Temperature effect on microbial community of enhanced biological phosphorus removal system. Water Res 37:409-415

Rosselló-Mora RA, Wagner M, Amann R, Schleifer KH (1995) The abundance of Zoogloea ramigera in sewage treatment plants. Appl Environ Microbiol 61:702-707

Satoh H, Mino T, Matsuo T (1994) Deterioration of enhanced biological phosphorous removal by the domination of microorganisms without polyphosphate accumulation. Water Sci Technol 30:203-211

Saunders AM, Oehmen A, Blackall LL, Yuan Z, Keller J (2003) The effect of GAOs (glycogen accumulating organisms) on anaerobic carbon requirements in full-scale Australian EBPR (enhanced biological phosphorus removal) plants. Water Sci Technol 47:37-43

Tay STL, Zhuang WQ, Tay JH (2005) Start-up, microbial community analysis and formation of aerobic granules in a tert-butyl alcohol degrading sequencing batch reactor. Environ Sci Technol 39:5774-5780

Whang LM, Park JK (2002) Competition between polyphosphate- and glycogen-accumulating organisms in biological phosphorus removal systems - effect of temperature. Water Sci Technol 46:191-194

Whang LM, Park JK (2006) Competition between polyphosphate- and glycogen-accumulating organisms in enhanced-biologicalphosphorus-removal systems: effect of temperature and sludge age. Water Environ Res 78:4-11

Wilen B-M, Onuki M, Hermansson M, Lumley D, Mino T (2008) Microbial community structure in activated sludge floc analysed by fluorescence in situ hybridization and its relation to floc stability. Water Res 42:2300-2308

Williams JC, Reyes FLD (2006) Microbial community structure of activated sludge during aerobic granulation in an annular gap bioreactor. Water Sci Technol 54:139-146

Zitomer DH, Duran M, Albert R, Guven E (2007) Thermophilic aerobic granular biomass for enhanced settleability. Water Res 41:819-825 